\title{
UNIFIKASI THIBBUN NABAWI REBUSAN SIRIH HIJAU PADA IBU PASCA SALIN DENGAN ROBEKAN PERINEUM DI PKD SRI REJEKI PLUPUH SRAGEN
}

\author{
Enny Yuliaswati ${ }^{1}$, Kamidah $^{2}$ \\ 1) Dosen STIKES ‘Aisyiyah Surakarta \\ 2) Dosen STIKES 'Aisyiyah Surakarta \\ E-mail: ennyyuliaswati@gmail.com ${ }^{1)}$,kamidahsantoso@gmail.com ${ }^{2)}$
}

\begin{abstract}
Lack of cleanliness in the genetal area is a problem that is commonly found in post-saline mothers especially with perineal tears. Care for the genetal area of the puerperal mother is important because it can prevent odor and accelerate the healing of the perineum. The presence of injuries to body tissues is very risky of infection. The potential for infection in the perineum because the perineum in the puerperal mother is a moist area. Nursing perineal sutures using green betel stew is effective to speed up the drying of the stitches. Community service is to increase knowledge about perineal suture care using green betel stew. This service was carried out for one month in the form of health promotion through home visits to perform perineal care with seams with green betel stew. interactive discussion with material about how to early detect cervical cancer. Based on observations during community service activities, several positive results were obtained, such as: 1). Postpartum mothers with perineal sutures consisting of 12 postpartum mothers. 2). Community service participants gave positive responses. 3) The healing period of perineal suture occurs within 4-5 days. The conclusion of this activity is health promotion with home visits can increase knowledge about how to care for perineal sutures.
\end{abstract}

Keywords: Perineum rupture; Green betel stew; Health promotion

\section{PENDAHULUAN}

Setiap proses persalinan normal berpotensi menyebabkan robekan pada perineum. Robekan perineum yang diakibatkan oleh proses persalinan pervaginam bermacammacam tingkatannya. Tingkatan robekan pada perineum dimulai dari tingkat ringan sampai totalis. Tingkatan ringan bila hanya mengenai selaput lendir vagina dan jaringan. Tingkatan sedang bila mengenai mukosa vagina, jaringan ikat, dan otot di bawahnya tetapi tidak mengenai spingter ani. Tingkat robekan perineum totalis bila sampai mengenai spingter ani.

Keberadaan luka pada jaringan tubuh sangat berisiko terjadi infeksi. Potensial 
terjadinya infeksi pada perineum karena perineum pada ibu nifas merupakan daerah yang lembab. Pengeluaran lokhea dan kebersihan yang kurang akan mempermudah masuknya kuman sehingga terjadi infeksi.

Kurangnya kebersihan pada daerah genetalia merupakan permasalahan yang banyak ditemukan pada ibu pasca salin terutama dengan robekan perineum. Kebersihan genetalia yang kurang baik, walaupun genetalia merupakan organ intim pada wanita, namun banyak penyebab yang menyebabkan hal tersebut terjadi. Penyebab kebersihan genetalia yang kurang baik antara lain karena pengetahuan yang kurang dan kekhawatiran akan merasakan sakit apabila menyentuh daerah genetalia.

Perawatan daerah genetalia pada ibu nifas penting dilakukan karena bisa mencegah bau dan mempercepat penyembuhan perineum.

\section{MASALAH, TARGET DAN LUARAN}

Permasalahan tentang perawatan pasca salin, terutama mengenai perawatan perineum yang dilakukan secara mandiri oleh ibu nifas, didapatkan informasi kalau mayoritas ibu nifas kesulitan merawat perineum karena keterbatasan informasi yang bisa diperoleh.
Hasil survey pendahuluan pada $10 \mathrm{ibu}$ nifas dengan jahitan perineum diperoleh data; semua ibu-ibu mengerti tentang robekan perineum dan jahitan perineum, namun belum pernah mendapat informasi tentang perawatan perineum dengan rebusan air sirih hijau.

Target pada kegiatan tersebut adalah terselenggaranya promosi kesehatan pada ibu nifas dengan jahitan perineum yang merupakan anggota kelompok mitra. Sedangkan luaran yang dihasilkan pada kegiatan tersebut adalah peningkatan pengetahuan tentang cara perawatan perineum dengan rebusan air sirih hijau dan bersedia melakukannya secara mandiri sampai jahitan perineum mengering.

\section{METODE PELAKSANAAN}

Kegiatan pengabdian masyarakat dengan tema "Unifikasi thibbun nabawi rebusan sirih hijau pada ibu pasca salin dengan robekan perineum" dilaksanakan melalui promosi kesehatan tentang perawatan perineum dan melatih perawatan perineum yang dilakukan dengan kunjungan rumah. Kunjungan rumah dilakukan karena masa perawatan di Poliklinik Kesehatan Desa berlangsung 1-2 hari. Menjelang pasien pulang, pengabdi memberikan promosi kesehatan tentang cara perawatan masa nifas secara umum. 
GEMASSIKA: Jurnal Pengabdian Kepada Masyarakat

Vol. 4 No. 1 Mei 2020

Promosi kesehatan yang dilakukan pada hari ke-1-2 memiliki keterbatasan yaitu kurang efektif diterima oleh pasien, karena masih dalam fase taking in, pada fase itu ibu nifas berfokus pada diri sendiri dan pengalaman bersalinnya. Waktu kegiatan selama 3 bulan, bulan Februari 2019 - bulan April 2019.

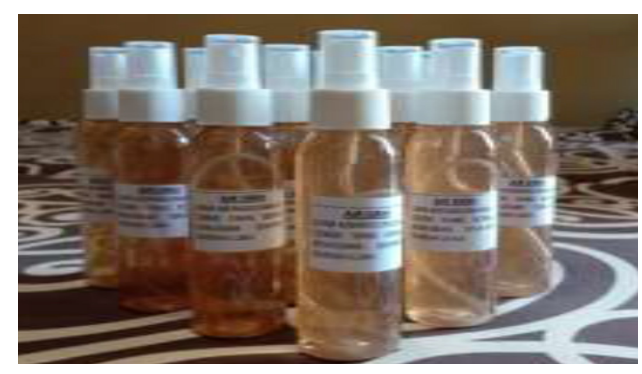

Gambar1.

Rebusan sirih hijau dalam bentuk spray

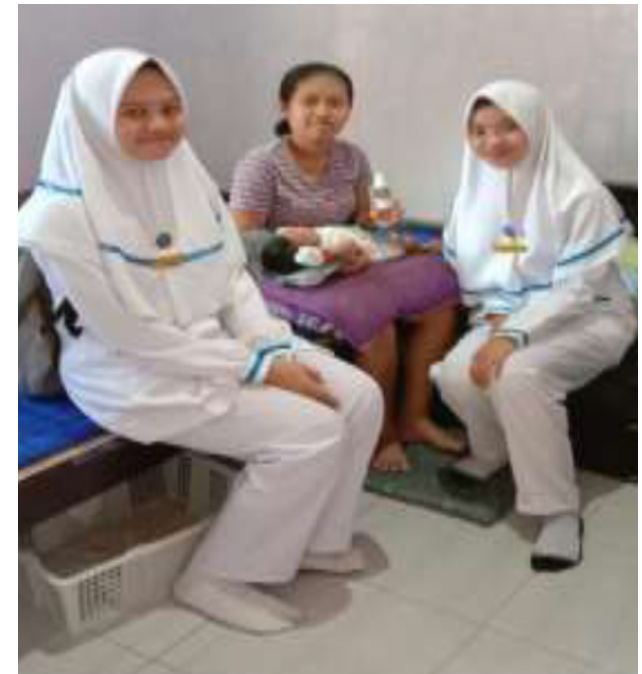

Gambar 2.

Kegiatan pelaksanaan pengabdian masyarakat

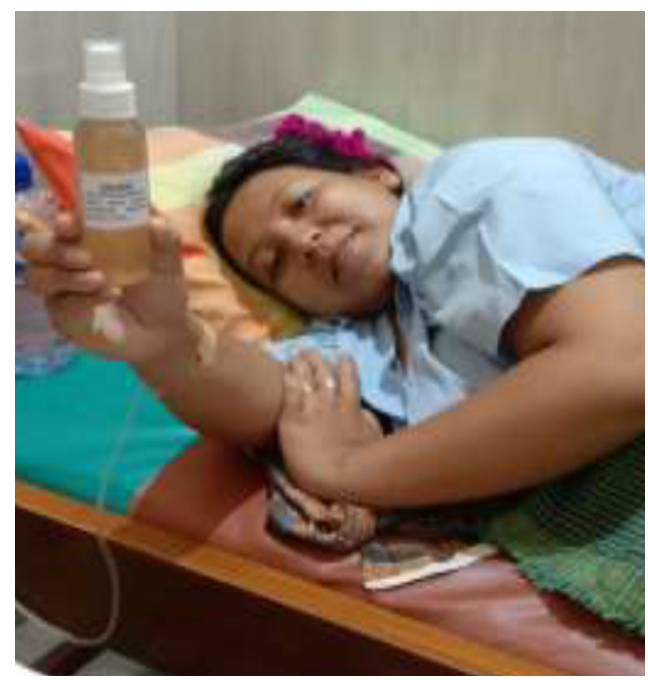

Gambar 3.

Salah satu pesesrta pengabdian masyarakat 
Kegiatan pengabdian masyarakat ini dilaksanakan pada ibu-ibu nifas dengan jahitan perineum di PKD Sri Rejeki Dwi Hastuti, Plupuh, Sragen. Berdasarkan pengamatan penulis, ibu-ibu nifas yang bersalin di PKD Sri rejeki Dwi Hastuti, Plupuh, Sragen tersebut merupakan persalinan yang pertama yang rata-rata berumur 21-30 tahun. Usia tersebut masuk dalam rentang usia reproduksi sehat, bisa disimpulkan usia yang aman untuk hamil dan melahirkan. Pasien sebagai sasaran pengabdian masyarakat adalah ibu nifas yang baru melahirkan pertama, sehingga dalam proses persalinannya mengalami robekan perineum yang perlu dilakukan penjahitan. Kegiatan tersebut dilakukan pada $10 \mathrm{ibu}$ nifas yang melahirkan di PKD Sri Rejeki Dwi Hastuti.

Usia yang masih muda dari para ibu nifas dan tidak adanya pengalaman sebelumnya, membuat mayoritas ibu nifas kurang benar cara merawat perineumnya. Perineum pada masa nifas yang dilakukan penjahitan memerlukan perhatian dan perawatan yang memadai. Perhatian dan perawatan perineum saat nifas, diperlukan agar tidak terjadi infeksi. Terjadinya infeksi pada perineum yang dijahit bisa karena kondisi perineum yang basah dan vagina yang mengeluarkan lochea, sehingga perlu perawatan perineum.
Penelitian yang dilakukan oleh Nurahmaton dan Sartika (2017) menyatakan bahwa perawatan pada jahitan perineum akan mengalami penyembuhan yang lebih cepat bila ibu nifas bisa merawatnya dengan benar. Perawatan perineum dengan jahitan bisa dilakukan dengan benar bila ibu memiliki pengetahuan yang memadai etntang perawatan jahitan perineum. Sebaliknya, ibu yang pengetahuannya kurang tentang perawatan jahitan perineum, maka perilaku selanjutnya dalam merawat jahitan perineum juga tidak benar.

Mayoritas ibu nifas abai dalam merawat perineum karena khawatir merasa sakit bila menyentuh daerah kelamin dan khawatir jahitan perineumnya akan terlepas. Kondisi tersebut, semakain memperparah jahitan perineum yang semakin lembab karena lokhea tertahan di sela-sela benang jahitan. Tertahannya lokhea di sela-sela jahitan perineum, menyebabkan penyembuhan dan proses pengeringan jahitan perineum terhambat.

Perawatan perineum umumnya membutuhkan waktu 6-7 hari untuk kering. Penelitian yang dilakukan oleh penulis di PKD Panjawi Sukoharjo tahun 2016, bahwa air rebusan sirih hijau efektif mempercepat pengeringan jahitan perineum. Jahitan 


\section{GEMASSIKA: Jurnal Pengabdian Kepada Masyarakat}

Vol. 4 No. 1 Mei 2020

perineum yang dirawat dengan air rebusan sirih hijau rata-rata kering dalam waktu 4-5 hari. Sedangkan jahitan perineum yang tidak dirawat dengan air rebusan sirih hijau rata-rata kering dalam waktu 6-7 hari. Bisa disimpulkan bahwa air rebusan sirih hijau efektif untuk merawat perineum dengan jahitan (Yuliaswati dan Kamidah)

Untuk memecahkan masalah tersebut, dilakukan promosi kesehatan tentang perawatan perineum menggunakan air rebusan daun sirih dalam botol yang berbentuk spray melalui kunjungan rumah. Pelaksanaan pengabdian pada bulan Juli 2019 di PKD Sri Rahayu Dwi Hastuti. Penulis melakukan kunjungan rumah pada pasien yang bersalin di di PKD Sri Rahayu Dwi Hastuti.

Penelitian yang dilakukan Damarini, Eliana dan Mariati (2012) pada 5 bidan praktik mandiri Kota Bengkulu, menemukan dari 10 pasien persalinan rata-rata yang mengalami ruptur spontan atau episiotomi ada 7 pasien dan kering rata-rata dalam 7 hari. Semakin lama waktu yang diperlukan perineum untuk kering, maka potensi terjadi infeksi semakin besar. Sedangkan perawatan dengan menggunakan infusum sirih merah memerlukan waktu rata-rata untuk kering 2-3 hari.
Promosi kesehatan tentang perawatan perineum yang dilakukan dengan kunjungan rumah, mengajarkan untuk mencuci perineum dengan sabun sampai bersih. Selesai cebok kemudian mengeringkan perineum dengan handuk atau tissu sampai kering kemudian mnyemprotkan air rebusan daun sirih pada jahitan perineum. Langkah terakhir perawatan perineum berikutnya adalah mengganti pembalut dengan pembalut yang bersih sebelum menggunakan celana dalam.

Pengukuran apakah promosi kesehatan dalam pengabdian masyarakat tentang perawatan perineum bisa diterima dengan baik oleh ibu nifas, yaitu dengan melakukan kunjungan ulang pada hari berikutnya. Kunjungan ulang pada ibu nifas dengan jahitan perineum yang dirawat dengan air rebusan sirih hijau bertujuan untuk menilai efektifitas kegiatan. Kegiatan promosi kesehatan tentang perawatan perineum menggunakan rebusan daun sirih hijau yang dilakukan melalui kunjungan rumah terbukti efektif ditandai dengan ibu- ibu nifas bisa mempraktikkan kembali perawatan perineum dengan air rebusan sirih hijau yang diberikan oleh penulis.

Ibu-ibu nifas merasa mendapat manfaat yang besar dari kegiatan pengabdian masyarakat ini. Ibu-ibu nifas merasa pengabdian 
dalam bentuk semacam itu untuk sering dilakukan karena langsung bisa diaplikasikan. Banyak manfaat yang diperoleh dengan adanya kegiatan pengabdian masyarakat tersebut, kegiatan tersebut bisa mendekatkan hubungan antara STIKES 'Aisyiyah Surakarta yang terdiri dari mahasiswa, dosen, civitas akademik dengan masyarakat umum. Kegiatan pengabdian masyarakat tersebut memberikan dampak positif untuk promosi keberadaan STIKES 'Aisyiyah Surakarta kepada masyarakat.

Berdasarkan hasil tersebut, maka pengabdian masyarakat yang berkelanjutan menggunakan teknologi tepat guna dengan materi-materi baru yang berdampak langsung oleh masyarakat.

\section{SIMPULAN DAN SARAN}

Kegiatan pengabdian masyarakat di PKD Sri Hastuti Dwi Hastuti, Plupuh, Sragen dapat terlaksana dengan lancar. Ibu-ibu nifas sangat antusias menerima penjelasan dari penulis tentang perawatan perineum menggunakan air rebusan sirih hijau. Kegiatan masyarakat tersebut terbukti dapat meningkatkan pengetahuan masyarakat tentang cara dan pentingnya perawatan perineum.

Tanggapan masyarakat dan bidan penanggungjawab Poliklinik Kesehatan Desa, sangat baik, sehingga bisa ditidaklanjuti sebagai daerah binaan.

\section{DAFTAR PUSTAKA}

Damarini. S, Eliana, Mariati. (2013). Efektifitas sirih merah dalam perawatan luka perineum di Bidan Praktik Mandiri. Jurnal.fkm.ui.ac.id/kesmas/article/download/340/339. Diakses 05 April 2020

Nurahmaton, Sartika, D. (2017). Hubungan Pengetahuan Ibu Post Partum Tentang Perawatan Luka Perineum dengan Proses Penyembuhan Luka di Klinik Bersalin Hj. Nirmala Sapni, Amkeb Medan. https://www.researchgate.net/publication/329742312. Diakses 05 April 2020

Rohan, H. Dkk. (2017) Buku kesehatan reproduksi. Pengenalan penyakit menular reproduksi dan pencegahan. Intimedia 
GEMASSIKA: Jurnal Pengabdian Kepada Masyarakat

Vol. 4 No. 1 Mei 2020

Sofian. A. (2011). Rustam Mochtar Sinopsis obstetri. Jilid 1. EGC

Varney, H.(2013) Buku Ajar Asuhan Kebidanan ed 4.EGC; Jakarta

Yuliaswati E dan Kamidah. (2017). Upaya Mempercepat Penyembuhan Luka Perineum Melalui Penggunaan Air Sirih Hijau http://ejournal.ijmsbm.org/index.php/ijms/article/ view/139/139

46 Unifikasi Thibbun Nabawi Rebusan Sirih Hijau... 